\title{
Technical Evaluation and Boezem Bratang Operation Patterns In Surabaya
}

\author{
Akhmad Lutfis Salamin \\ Civil Engineering Department \\ Narotama University \\ Surabaya, Indonesia \\ akhmad.lutfis90@gmail.com
}

\begin{abstract}
Surabaya is the second largest and most populous city in Indonesia and is inseparable from the problem of flooding which is still flooded the area of East Surabaya. Flooding is caused by Bratang boezem unable to accommodate rainwater discharge. Boeang Surabaya has an area of $19,900 \mathrm{~m} 2$, has two systems namely flood gates and flood pumps. The floodgate system will work to drain the boezem bratang water to wonokromo river if the water elevation at Wonokromo River is at under the elevation of Bratang boezem water and flow Gravitatively while the pump system will work if the floodgate system is no longer functioning. To overcome the problem of flooding in the region, it is necessary to conduct hydrological and hydraulics analysis by performing boezem routing to determine the Boezem capacity whether it can accept the planned rain discharge. a depth of $3 \mathrm{~m}$ is unable to accommodate a maximum flood discharge period of 2.5 and 10 years. so it is planned to increase the boezem depth which was originally $3 \mathrm{~m}$ to $4.6 \mathrm{~m}$, and increase the pump capacity which was originally from $10.5 \mathrm{m3} / \mathrm{s}$ to $14 \mathrm{~m} 3 / \mathrm{s}$.From the plan, after the hydrologic and hydraulics analysis using Boezem routing, Boezem has been able to accommodate the planned rain discharge.
\end{abstract}

Keywords: Flood, Boezem, pump capacity.

\section{INTRODUCTION}

Surabaya is the second largest and most populous city in Indonesia. The development of the City of Surabaya is leading to the growth of industrial activities, trade and services, as well as settlements. With this development, if the construction of facilities and infrastructure of urban drainage is not carried out, floods will occur.One area that is still flooded during every heavy rain in the East Surabaya area is Jl. Ngagel Rejo Kidul, Jl. Ngagel Kebon Sari (SMP Negeri 12), Jl. East Ngagel, and the Bratang Binangun area (Primary survey, 2018). The area is included in the Bratang boezem drainage system.Bratang boezem is one of the causes of flooding in the area due to the boezem which is unable to accommodate rainwater discharge.

The formulas which will be discussed are as follows:

1. What is the Bratang's existing boezem capacity for existing flood discharges?

2. How does Bratang's boezem operation pattern suit the current conditions?

3. How to plan the right Bratang boezem based on the evaluation results?

The objectives of this research are as follows:

1. Knowing Bratang's existing boezem capacity.

2. Knowing the Bratang boezem operating pattern that suits the current conditions.

3. Obtain alternative planning for the right Bratang boezem. 


\section{RESEARCH METHODOLOGY}

\section{Flow Chart / Flow Chart}

For the steps in preparing the Final Project can be seen in the Flow Chart as follows:

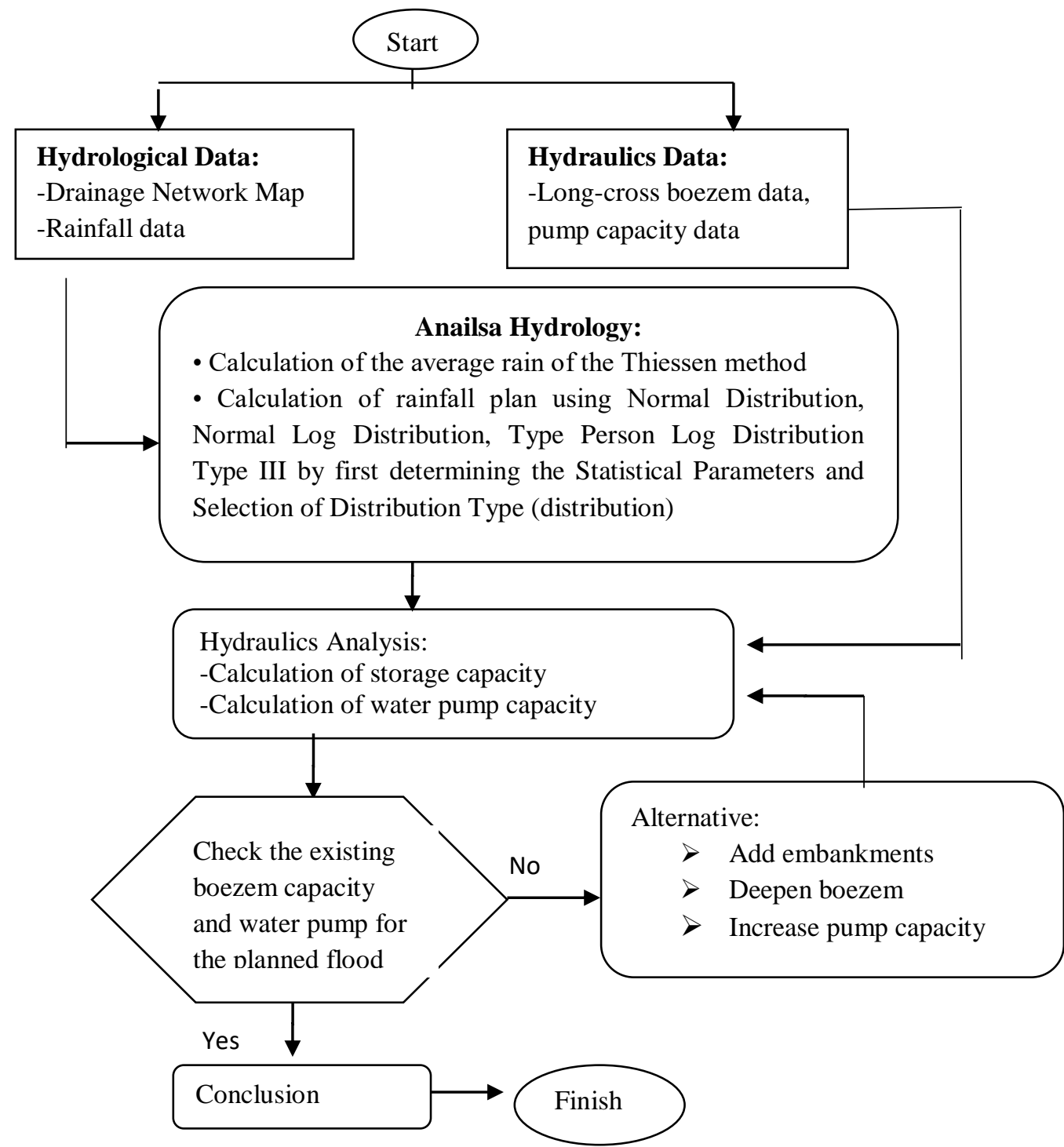

\section{Hydrological Analysis}

\section{RESULT AND DISCUSSION}

Hydrological analysis is used to determine the amount of flood discharge plans in a water building plan. The steps in hydrological analysis are as follows.

\section{Analysis of Plan Rain}

The rainfall data used in this analysis is the maximum rainfall data there are only two rainfall stations that have an area of influence in the Boezem Bratang Watershed. The two stations are:

1. Gunungsari rain observation station

2. Wonokromo rain observation station 
Volume 03 Number 01 September 2019

Table 1. Area Effect and Thiessen Coefficient for Each Rain Station

\begin{tabular}{cccc} 
No. & Rain Station & $\begin{array}{c}\text { Area of Station } \\
\text { influential }\left(\mathrm{km}^{2}\right)\end{array}$ & Quality \\
\hline 1 & 2 & 3 & 4 \\
1 & Gunungsari & 0.013 & 0.004 \\
2 & Wonokromo & 3.647 & 0.996 \\
& Total Area & 3.660 & 1.000 \\
\hline
\end{tabular}

(Source: Calculation results)

Table 2. Maximum Average Rainfall

\begin{tabular}{ccccc}
\hline \multirow{2}{*}{ No. } & \multirow{4}{*}{ Year } & \multicolumn{2}{c}{ R At Rain Station } & Rmax \\
& & Gunungsari & Wonokromo & \\
\hline 1 & 2004 & 0.31 & 114.58 & 114.58 \\
2 & 2005 & 47.16 & 67.90 & 67.90 \\
3 & 2006 & 113.00 & 113.00 & 113.00 \\
4 & 2007 & 0.36 & 75.72 & 75.72 \\
5 & 2008 & 92.04 & 92.04 & 92.04 \\
6 & 2009 & 60.20 & 95.03 & 95.03 \\
7 & 2010 & 47.23 & 99.86 & 99.86 \\
8 & 2011 & 36.22 & 106.87 & 106.87 \\
9 & 2012 & 70.04 & 80.80 & 80.80 \\
10 & 2013 & 103.90 & 103.90 & 103.90 \\
11 & 2014 & 15.36 & 109.93 & 109.93 \\
12 & 2015 & 98.01 & 98.01 & 98.01 \\
13 & 2016 & 105.99 & 105.99 & 105.99 \\
14 & 2017 & 87.04 & 87.04 & 87.04 \\
15 & 2018 & 83.01 & 83.01 & 83.01 \\
\hline \multicolumn{5}{c}{ Total } \\
\hline
\end{tabular}

(Source: Calculation results)

\begin{tabular}{|c|c|c|c|c|c|}
\hline No. & Distribusi & $\begin{array}{c}\text { Parameter } \\
\text { Statisfik }\end{array}$ & Syarat & Hitungan & $\begin{array}{c}\text { Kesimpulan } \\
\text { syarat }\end{array}$ \\
\hline \multirow{2}{*}{1} & \multirow{2}{*}{ Normal } & $C_{-} S$ & sama / mendekati = 0 & -0.48 & Tidak memenuhi \\
\hline & & $C_{-} k$ & sama/mendekati $=3$ & 2.84 & Tidak memenuhi \\
\hline \multirow{2}{*}{2} & \multirow{2}{*}{ Gumbel } & C_S & sama / mendekati $\leq 1.14$ & -0.48 & Memenuhi \\
\hline & & $C_{-} k$ & sama / mendekati $\leq 5.4$ & 2.84 & Memenuhi \\
\hline \multirow{2}{*}{3} & \multirow{2}{*}{$\begin{array}{c}\text { Log Pearson } \\
\text { type III }\end{array}$} & $C_{-} S$ & \multirow{2}{*}{ Selain dari nilai di atas } & -0.72 & Memenuhi \\
\hline & & $C_{-} k$ & & 3.26 & Memenuhi \\
\hline \multirow{2}{*}{4} & \multirow{2}{*}{ Log Normal } & $C_{-} S$ & $\mathrm{Cs}=\mathrm{Cv}^{3}+3 \mathrm{Cv}=3$ & 0.10 & Tidak memenuhi \\
\hline & & $C_{-} k$ & $\mathrm{Ck}=\mathrm{Cv}^{8}+6 \mathrm{Cv}^{6}+15 \mathrm{Cv}^{4}+16 \mathrm{Cv}^{2}+3=5.383$ & 3.02 & Tidak memenuhi \\
\hline
\end{tabular}

Table 3. Selection of Appropriate Distribution Types

(Source: Calculation results) 
Volume 03 Number 01 September 2019

From the table above, it can be seen that the type of distribution that meets the requirements and can be used in this thesis is the Pearson Type III log distribution and Gumbel distribution.

Table 4. Match Test Recapitulation

\begin{tabular}{|c|c|c|c|c|c|c|c|}
\hline \multirow{2}{*}{$\begin{array}{l}\text { Distribution } \\
\text { Type }\end{array}$} & \multicolumn{3}{|c|}{ Chi Square Test } & \multicolumn{4}{|c|}{$\begin{array}{c}\text { Kolmogorov Smirnov } \\
\text { Test }\end{array}$} \\
\hline & $X h^{2}$ & $\mathrm{X}^{2} \mathrm{kr}$ & Ket & $\mathrm{D}_{\text {maks }}$ & & Do & Ket \\
\hline $\begin{array}{c}\text { Log Person } \\
\text { Type III } \\
\text { Gumbel }\end{array}$ & $\begin{array}{l}4.00 \\
2.00\end{array}$ & $\begin{array}{r}5.991 \\
<\quad 5.991\end{array}$ & Ok & $\begin{array}{l}0.101 \\
0.097\end{array}$ & $<$ & $\begin{array}{l}0.34 \\
0.34\end{array}$ & Ok \\
\hline
\end{tabular}

the type of distribution that can be used to calculate the planned rainfall is the Gumbel distribution. Calculation of rainfall plan with the Gumbelm distribution using statistical parameters taken. The parameters used are as follows:

$$
\begin{array}{ll}
\text { Average value }(\overline{\mathrm{x}}) & =95,58 \\
\text { Standard deviation }(\mathrm{S}) & =14,20 \\
\text { Total of data }(\mathrm{N}) & =15 \\
\text { Yn } & =0,5128 \\
\text { Sn } & =1,0206 \\
\text { For } & =2 \text { Year } \\
\text { T } & =-\ln \left[-\ln \frac{2-1}{2}\right]=0,367 \\
\text { Yt } & =95,58+\frac{0,367-0,5128}{1,0206} \times 14,20=93,54 \mathrm{~mm} \\
\mathrm{X} & =5 \text { Year } \\
\mathrm{T} & =-\ln \left[-\ln \frac{5-1}{5}\right]=2,250 \\
\mathrm{Yt} & =95,58+\frac{1,050-0,5128}{1,0206} \times 14,20=109,31 \mathrm{~mm} \\
\mathrm{X} & =10 \mathrm{Year} \\
\mathrm{T} & =-\ln \left[-\ln \frac{10-1}{10}\right]=2,250 \\
\mathrm{Yt} & =95,58+\frac{2,250-0,5128}{1,0206} \times 14,20=119,75 \mathrm{~mm} \\
\mathrm{X} &
\end{array}
$$

\begin{tabular}{|c|c|c|c|c|c|c|c|c|c|c|c|c|}
\hline \multirow{3}{*}{ No } & \multirow{3}{*}{ Sub Das } & \multirow{3}{*}{$\begin{array}{c}\text { Tr } \\
(\text { jam) }\end{array}$} & \multirow{3}{*}{$\begin{array}{c}\text { Tc } \\
\text { (menit } \\
)\end{array}$} & \multirow{3}{*}{$\begin{array}{c}\text { Tc } \\
(\text { jam) }\end{array}$} & \multicolumn{3}{|c|}{$\begin{array}{c}\text { Intensitas Curah Hujan } \\
\text { (mm/jam) }\end{array}$} & \multirow{3}{*}{$A\left(\mathrm{~km}^{2}\right)$} & \multirow{3}{*}{ C gab } & \multirow{3}{*}{$\mathbf{Q}_{2}$} & \multirow{3}{*}{ Q5 } & \multirow{3}{*}{$Q_{10}$} \\
\hline & & & & & 2 & 5 & 10 & & & & & \\
\hline & & & & & 92,99 & 105,86 & 111,95 & & & & & \\
\hline 1 & Saluran Barata Jaya 12 & 2,00 & 6 & 0,11 & 144 & 164 & 173 & 0,132 & 0,72 & 3,786 & 4,310 & 4,558 \\
\hline 2 & Saluran Barata Jaya 17 & 2,00 & 7 & 0,12 & 136 & 154 & 163 & 0,208 & 0,73 & 5,708 & 6,498 & 6,871 \\
\hline 3 & $\begin{array}{l}\text { Saluran primer } \\
\text { kalisumo }\end{array}$ & 2,00 & 21 & 0,35 & 65 & 74 & 79 & 1,300 & 0,72 & 16,969 & 19,317 & 20,428 \\
\hline 4 & Genangan & 2,00 & 60 & 1,00 & 32 & 37 & 39 & 0,339 & 0,72 & 2,186 & 2,489 & 2,632 \\
\hline
\end{tabular}

The results of the calculation of the plan date with a 2-year return period of $93.54 \mathrm{~mm} 5$ years $109.31 \mathrm{~mm}$ and 10 years $119.75 \mathrm{~mm}$. In the next calculation, the value of the rain plan is used to calculate the intensity of the rain.

\section{Calculation of Debit Plan}

Rational Debit Formula $(Q)=(1 / 3.6) \times C \times I \times A$

Calculation Q 2 Year $=(1 / 3.6) \times 0.68 \times 173.72 \times 0.1315$

$$
=4.318 \mathrm{~m}^{3} / \mathrm{de}
$$

Tabel 5. Rational Intensity and Debit Calculations 
Volume 03 Number 01 September 2019

\section{Calculation of Concentration Time}

Concentration time is defined as the time it takes for rainwater to fall at the farthest point from a stream area to reach an outlet.

Rumus Kirpich

$$
\mathrm{T}_{\mathrm{c}}=0.0195 \mathrm{~L}^{0.77} \mathrm{~S}^{-0.385}
$$

Where :

Tc $=$ concentration time $(\mathrm{min})$

$L=$ maximum flow length (meters)

$\mathrm{S}=$ slope of watershed difference in elevation between upstream and downstream divided by length

\section{Canal Barata jaya 12}

Known :

$$
\begin{aligned}
& \mathrm{L}=427,5 \text { meter } \\
& \mathrm{S}=0,0008 \\
& \mathrm{TC}=0,0195 \times 427,5^{0.77} \times 0,0008^{-0.385} \\
& =32,118 \text { minute or }=0,54 \text { hour }
\end{aligned}
$$

\section{Calculation for Rainwater Mononobe Intensity}

Example of Rain Intensity Calculation is as follows:

1. Canal Barata jaya 12

- Tc (hour) $=0.54$ hour

- R 24 (2 Year) = $92.99 \mathrm{~mm}$

Intensity Formula $(\mathrm{I})=\mathrm{R}_{24} / 24 \times(24 / \mathrm{t})^{2 / 3}(\mathrm{~mm} /$ hour $)$ (2).

Where: $\quad R_{24}=$ Maximum rainfall $(\mathrm{mm})$

$$
\begin{array}{ll}
\text { tc } & =\text { Time of rain concentration (jam) } \\
\mathrm{I} & =\text { Rainfall intensity }(\mathrm{mm} / \mathrm{jam})
\end{array}
$$

Calculation I $=(92.99 / 24) \times\left[(24) /\left\{(24 / 0.10)^{\wedge}(2 / 3)\right\}\right]$

$$
=173.72 \mathrm{~mm} / \mathrm{hour}
$$

\section{Calculation of hydrological Q according to Specific Repeat Periods}

Examples of hydrological $Q$ calculations with modern methods are as follows:SaluranBarata jaya 12

$-\mathrm{A}\left(\mathrm{km}^{2}\right)=0.1315 \mathrm{~km}^{2}$

$-\mathrm{I}(\mathrm{mm} /$ hour $)=173.72 \mathrm{~mm} /$ hour

\section{Evaluation of Bezem}

$$
-\mathrm{C} \text { gab }=0.68
$$

From the sketch of the figure below it is known that the basic elevation of the boezem +9.35 up to the normal water level elevation of +10.15 is called a dead storage. Boezem maximum water level elevation +12.20 . If the water exceeds the maximum water level elevation, the water in the boezem will return to the inflow channel (back water) and floods occur downstream of the inflow channel.

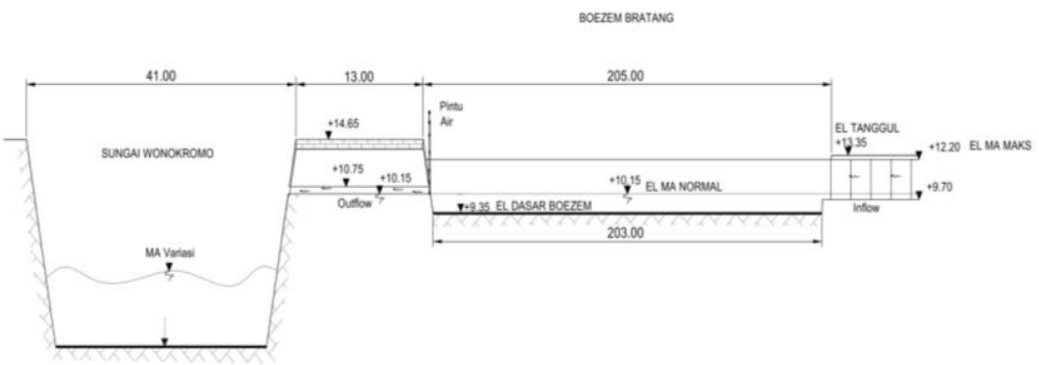


Volume 03 Number 01 September 2019

Figure 1. Existing Boezem Sketch with floodgates

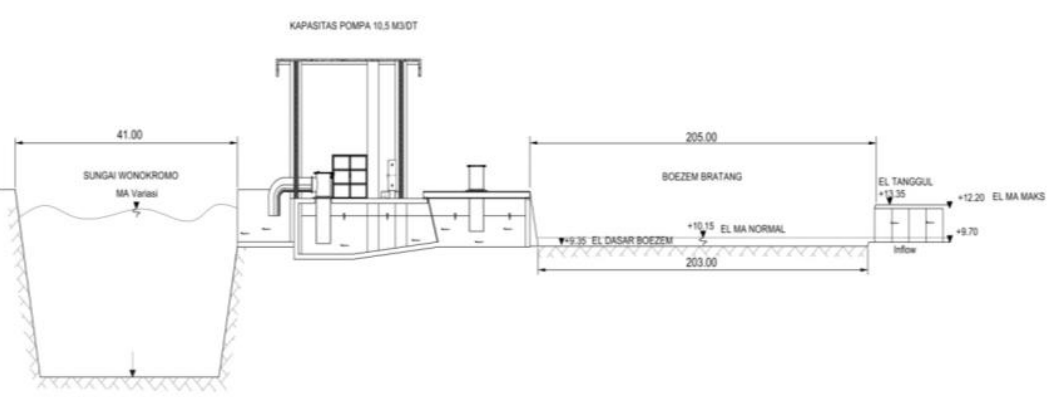

Figure 2. Existing Boezem sketch with pump

To check the boezem capacity with a depth of $3 \mathrm{~m}$, length $203 \mathrm{~m}$, width $98 \mathrm{~m}$, it is necessary to do flood tracking (Flood Routing) illustrated by the graph below.

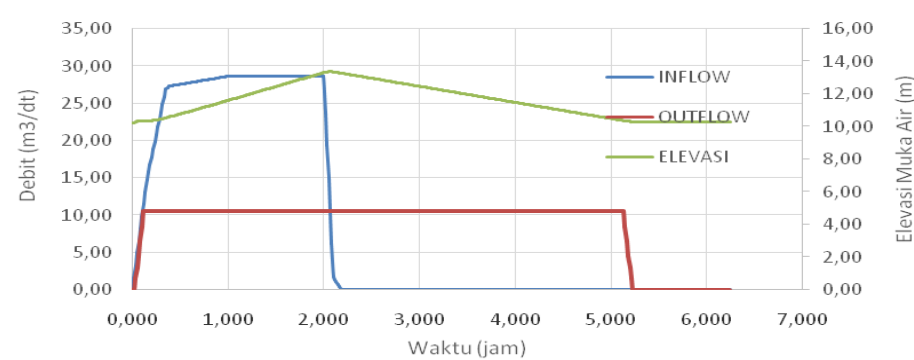

Figure 3. Routing Boeang Bratang $Q 2$ years existing

From Figure 3, it is known that the results of the calculation of the Boezem Bratang Routing $Q$ 2 , are still carried out in the Boezem Bratang with an evaluation of the maximum boezem water level of $+13.37 \mathrm{~m}$, the elevation of the channel $+9.35 \mathrm{~m}$, and the elevation of the embankment $+12.35 \mathrm{~m}$. The results of the simulations show that the comparison of the calculation of Routing Boezem Bratang has a maximum water level gap of $1.02 \mathrm{~m}$.

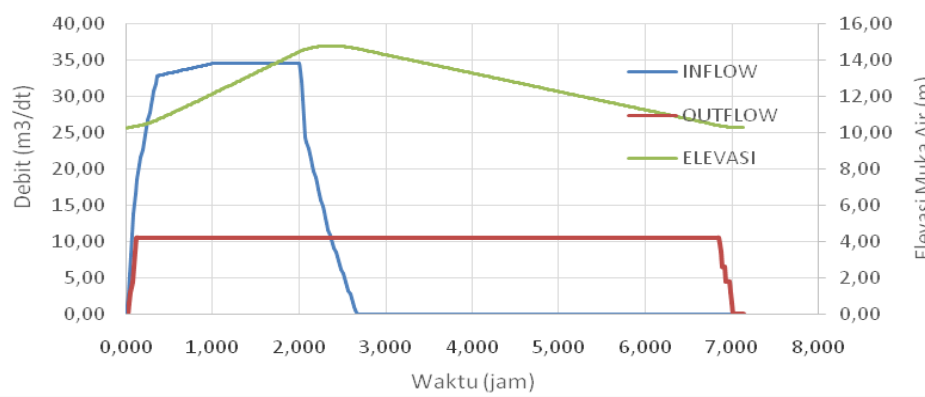

Figure 4. Existing 10 year old Boezem Bratang $Q$ routing

From Figure 4, it is known that the results of the calculation of the Boezem Bratang Routing $Q$ 10 , are still carried out in the Boezem Bratang with an evaluation of the maximum boezem water level of $+14.77 \mathrm{~m}$, the elevation status of the channel $+9.35 \mathrm{~m}$, and the elevation of the waterway $+12.35 \mathrm{~m}$. The results of the simulation show that the comparison between the calculation of Boezem Bratang Routing has a maximum water level difference of $2.42 \mathrm{~m}$.

\section{Boesem Bratang operating patterns}

Boesem Bratang functions as a drainage system which drains rainwater and household wastewater to the Wonokromo River and goes directly to sea. 
Boezem Bratang which has an area of $19,900 \mathrm{~m} 2$, has an outflow channel consisting of two systems namely flood gates and flood pumps, each of which has its own function and capacity.

a. The sluice system will work flowing boezem bratangke water in Wonokromo River if the water level in Wonokromo River is under the elevation of Bratang boezem water and flows Gravitatively.

b. This flood pump system will work if the floodgate system is no longer functioning.

\section{Planning Boesem Bratang}

The author plans to deepen $160 \mathrm{~cm}$ of Boezem Bratang and increase the pump capacity from $10.5 \mathrm{~m} 3 / \mathrm{s}$ to $14 \mathrm{~m} 3 / \mathrm{s}$.

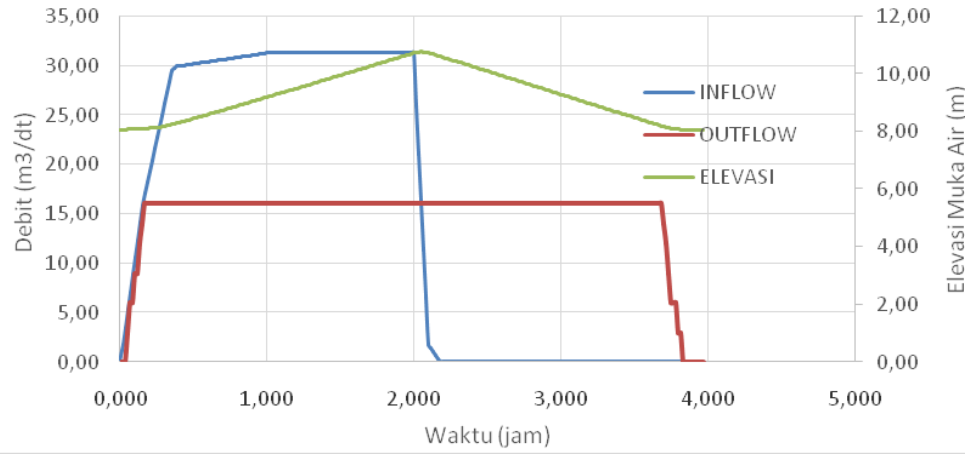

Figure 5. Boezem Bratang Routing $Q 2$ years Plan

The results of the calculation of the Boezem Bratang Q 2 Routing, there is no overflow in Boezem Bratang with a maximum boezem water level elevation of $+10.76 \mathrm{~m}$, elevation of the boezem embankment $+12.35 \mathrm{~m}$. The simulation results show that the Bratang boezem is still able to accommodate the 2 yearly rainfall discharge by deepening the $1.6 \mathrm{~m}$ boezem and the additional capacity of the Flood Pump.

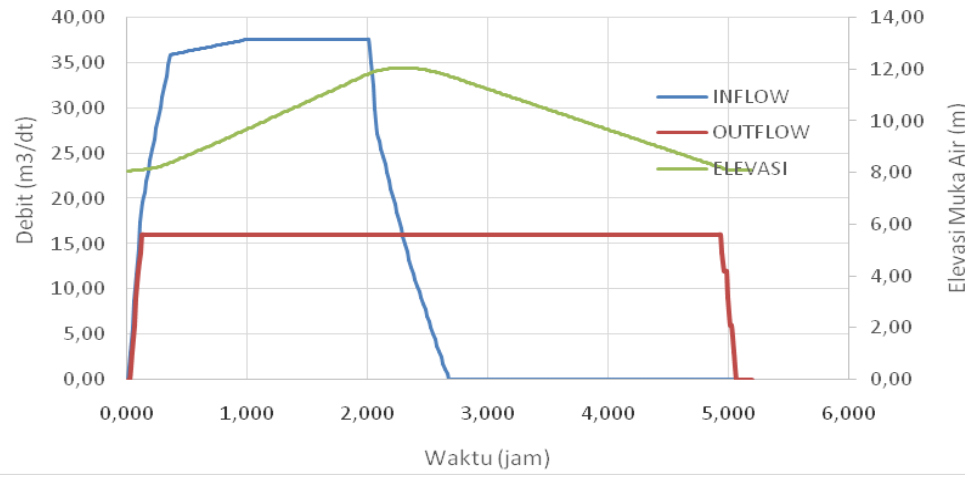

Figure 6. Boezem Bratang Routing Q 10 years Plan 
From Figure 6 it is known that from the calculation of Boezem Bratang Q 10 Routing, there is no overflow in Boezem Bratang with a maximum boezem water level elevation of $+12.07 \mathrm{~m}$, elevation of the boezem embankment $+12.35 \mathrm{~m}$. Simulation results show that the Bratang boezem is still capable of accommodating 10 yearly rainfall discharges by deepening the 1.6 $\mathrm{m}$ boezem and the additional capacity of the Flood Pump.

Figure 7. Boezem Bratang Plan after deepening and increasing flood pump capacity.

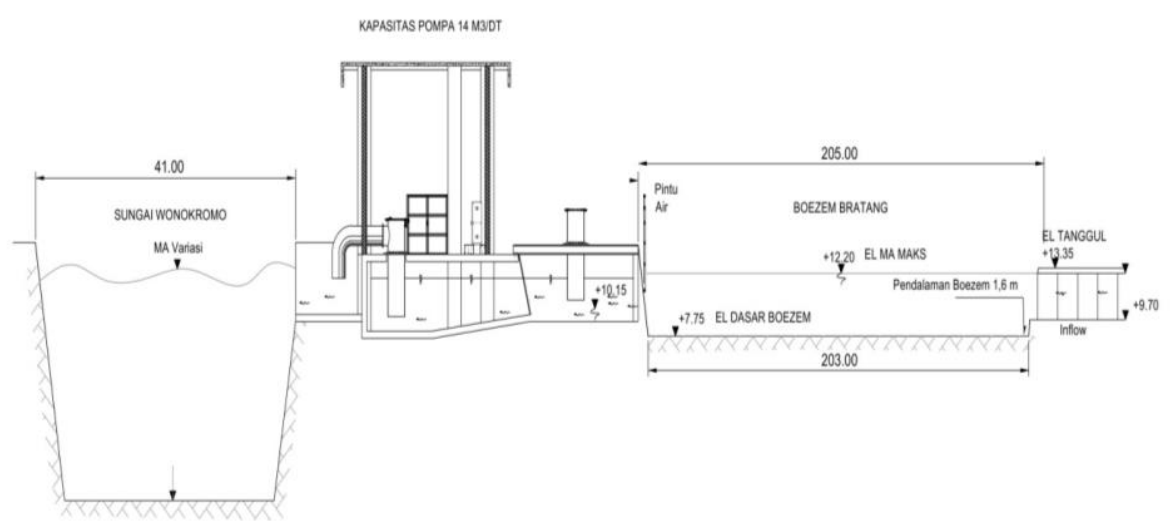

\section{CONCLUSIONS}

\section{Conclusions}

Based on the results of the analysis and discussion on the work of the Technical Evaluation Final Project and the Bratang Boezem Operation pattern in Surabaya, the following conclusions can be drawn:

1. The existing Boezem Bratang is unable to accommodate the maximum flood discharge of the 2 Year and 10 Year Rain Return Period.

2. Bratang's Boezem Operation Pattern consists of two systems namely flood gates and flood pumps.

a. The sluice system will work to flow the boezem bratang water to the Wonokromo river if the water level at the Wonokromo river is below the Boezem Bratang water level and the flow of water flows Gravitatively,

b. This flood pump system will work if the floodgate system is no longer functioning.

3. Alternative to overcome the Bratang Boezem flood by deepening the $1.6 \mathrm{~m}$ depth of Boezem Bratang and increasing the pump capacity from $10.5 \mathrm{m3} / \mathrm{sec}$ to $14 \mathrm{~m} 3$ / sec with the following details:

a. flood pump number 1 originally a capacity of $1.5 \mathrm{~m} 3 / \mathrm{s}$. It became $3 \mathrm{~m} 3 / \mathrm{s}$.

b. flood pump number 2 capacity of $1.5 \mathrm{~m} 3 / \mathrm{s}$ to $3 \mathrm{~m} 3 / \mathrm{s}$.

c. flood pump number 3 capacity $1.5 \mathrm{~m} 3 / \mathrm{s}$ To $3 \mathrm{~m} 3 / \mathrm{s}$.

d. flood pump number 4 capacity $2 \mathrm{~m} 3 / \mathrm{sec}$ To $3 \mathrm{~m} 3 / \mathrm{sec}$.

e. flood pump number 5 capacity $2 \mathrm{~m} 3$ / s remain unchanged.

f. flood pump number 6 capacity $2 \mathrm{~m} 3$ / $\mathrm{s}$ remains no change.

\section{REFERENCES}

Harto, Sri. (1993). Hidrologi Terapan. Yogyakarta: Biro Penerbit MahasiwaTeknik Sipil UGM. Hastiningrum. (2005). Prediksi Inflow Waduk Berdasarkan Outflow Menggunakan Persamaan Kontinuitas. Media Teknik Sipil.

Ir.CD. SOEMARTO, B. D. (t.thn.). Hidrologi Teknik. Surabaya: Usaha Nasional.

Jaya, M. C. (2000). Surabaya Drainage Master Plan. Surabaya: MacDonald Cambridge UK \& PT. Tricon Jaya.

PermenPU. (2014). SISTEM DRAINASE PERKOTAAN. 
Volume 03 Number 01 September 2019

Suripin, D. I. (2004). Sistem Drainase Perkotaan Yang Berkelanjutan. Yogyakarta: Andi Offset. 